DOI: https://doi.org/10.34069/AI/2021.46.10.13

How to Cite:

Prokhorenko, L., Popovych, I., Sokolova, H., Yarmola, N., \& Forostian, O. (2021). Research on reflective-evaluative competence in pupils with intellectual disabilities. Amazonia Investiga, 10(46), 138-151. https://doi.org/10.34069/AI/2021.46.10.13

\title{
Research on reflective-evaluative competence in pupils with intellectual disabilities
}

\section{Дослідження рефлексивно-оцінної компетентності у школярів з порушеннями інтелекту}

Received: August 15, 2021

Accepted: October 31, 2021

\author{
Written by: \\ Lesia Prokhorenko ${ }^{45}$ \\ https://orcid.org/0000-0001-5037-0550 \\ Ihor Popovych ${ }^{46}$ \\ https://orcid.org/0000-0002-1663-111X \\ Hanna Sokolova ${ }^{47}$ \\ https://orcid.org/0000-0002-9913-1814 \\ Nataliia Yarmola ${ }^{48}$ \\ https://orcid.org/0000-0001-9374-5543 \\ Olga Forostian ${ }^{49}$ \\ https://orcid.org/0000-0001-6084-2160
}

\begin{abstract}
The aim is to conduct empirical research on the formation of reflective-evaluative competence in primary pupils with intellectual disabilities and to determine effective methods to develop it. Methods: tests with standardized questionnaires, methods for checking the logic of motivating dialogue, comparative analysis, quantitative and qualitative content-analysis. We established that disorders in the functioning of reflection in primary pupils are observed in changeable or unfamiliar situations: rejection to solve a problem, desire to simplify a task, justification of their inability, avoidance of difficulties. We registered that insufficient development of selfcontrol and self-esteem causes faults in programming and performing activity. We identified difficulties in verbalizing a plan of actions showing the respondents' inability to compare and substantiate practical and mental operations. Disorders in reflective-evaluative competence are insufficient development of reflection, self-control, self-esteem and selfcorrection that does not allow primary pupils to organize their mental actions purposefully.
\end{abstract}

\section{Анотація}

Метою $€$ емпіричне дослідження сформованості рефлексивно-оцінної компетентності молодших школярів 3 порушеннями інтелекту та визначення ефективних засобів iї формування. Методи: тести зі стандартизованими анкетами, методи перевірки логіки спонукального діалогу, порівняльний аналіз, кількісне i якісне контент-аналізування. Встановлено, що порушення функціонування рефлексії молодших школярів простежується у змінних або незнайомих ситуаціях: відмова від розв'язання, прагнення спростити завдання, виправдання своєї неспроможності, уникнення труднощів. Зафіксовано, що недостатній розвиток самоконтролю, самооцінки породжує недоліки програмування та виконання діяльності. Констатовано труднощі під час вербалізації плану дій, що $є$ неспроможністю респонденів порівнювати i обгрунтовувати практичні i розумові операції. Порушення рефлексивнооцінної компетентності $\epsilon$ недостатнім розвитком рефлексіі, самоконтролю, самооцінки та самокорекції, що не дає змоги

\footnotetext{
${ }^{45}$ Doctor of Psychological Sciences, Full Professor, Director of Mykola Yarmachenko Institute of Special Pedagogy and Psychology, Kyiv, Ukraine. ${ }^{46}$ Doctor of Psychological Sciences, Full Professor of the Department of Psychology, Kherson State University, Kherson, Ukraine.

${ }^{47}$ Doctor of Psychological Sciences, Associate Professor of Department of Defectology and Physical Rehabilitation, South Ukrainian National Pedagogical University named after K. D. Ushynsky, Odessa, Ukraine.

${ }^{48}$ Candidate of Pedagogical Sciences, Deputy Director of Mykola Yarmachenko Institute of Special Pedagogy and Psychology, Kyiv, Ukraine.

${ }^{49}$ Doctor of Pedagogical Sciences, Full Professor of Department of Defectology and Physical Rehabilitation, South Ukrainian National Pedagogical

University named after K. D. Ushynsky, Odessa, Ukraine.
} 


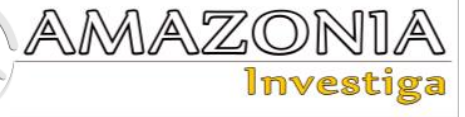

Key words: programming, competence, normaltypical development, intellectual development disorders, children with special needs.

\section{Introduction}

A strategic aim of teaching children with special educational needs is their full-fledged integration into society. It is important that such children could perceive intellectual-aesthetic values of society, adopt moral-ethical norms of human relationships and carry social loads on a par with their peers with normal-typical development. This problem is topical in the global dimension, in the context of tolerant attitude, formation of necessary competences and construction of inclusive educational space. The key role in education of pupils with special needs is played by reflective-evaluative competence. This is an internal intellectual process combining comparison of a purpose and conditions, identifying actual situation and experience of an individual, considering means and modes of transforming an object, developing a step-bystep strategy to solve a problem. We pay attention to the modern research on the integral system of indexes reflecting the quality of education of individuals with special educational needs (Shatskaya, 2021). The researcher states that regular monitoring of the quality of training people with disabilities and permanent support for them motivate to develop national intellectual capital.

The view of the followers of a subjective-activity approach on the interrelation between selfcontrol, self-esteem, self-correction and reflection as an integral psychological mechanism of regulation of an individual's activity is topical (Khmiliar et al., 2020; Mislavsky, 1988; Osnitskii, 2001). In this context it is necessary to mention the main principles of different theories in which an individual as an agent of activity is formed and developed in the process of "self-development", when quantitative newly formed structures are transformed into qualitative changes of personality structure, i.e. become internal acquisition (Prokhorov, 2005; Konopkin, 2012).

A. Osnitskii (2001) substantiated that an individual perceives and realizes the aim of the activity performed. According to the aim, they plan the succession of actions and evaluate the conditions to achieve it. The result of these actions is a молодшим школярам цілеспрямовано організовувати свої розумові дії.

Ключові слова: програмування, компетентність, нормотиповий розвиток, порушення інтелектуального розвитку, діти 3 особливими потребами.

subjective model of activity serving as a basis for making a program of actions, instruments and methods to implement it. Awareness of the aims of activity allows an individual to make decisions on the necessity to make changes to actions independently (Osnitskii, 2001). The researcher draws a conclusion that changes in an individual and in the instruments used to achieve the aim occur due to reflection.

The studies of the followers of the psychophysiological theory of teaching examine the interrelation of reflection and self-esteem as an important mechanism of an individual's regulatory competence. This mechanism allows forming criteria of estimations, making a search program, analyzing, generalizing and abstracting the instruments to achieve aims (Piaget, 1977; Shevchenko et al., 2020). The ability to reflect ensures the achievement of an intellectual aim and allows finding the unknown. The search is determined by forecasting optimal stages of solving a problem and predicting their consequences. The depth of forecasting is a necessary element of a reflective component of an individual's competence providing an opportunity to find a rational method to achieve the aim (Romanenko, 2020; Torrance, 1974).

Reflective-forecasting processes serve as a basis for the formation of criteria of a choice, the determination of criteria of regulation of a particular activity (Martel, 2007; Kopp, 1982). The authors state that in conscious activity the accent is not on a choice, but on criteria making such a choice possible, i. e. effectiveness of regulation depends on the succession of reflective acts.

The research conducted within the area of a neuropsychological approach show that a reflection act depends on the development of the reticular formation (Lubovsky, 1989; Luria, 1996). The scientists believe that frontal lobe damage causes disorders in planning the succession of actions and the processes related to control of performing an activity and making corrections to a planned activity. A lack of wellformed reflection causes a disorder in 
programming and pathological changes in the processes of regulation and control, inability to perceive and retain a task, direct mental activity towards solving a problem.

The scientists highlight that the phenomenon of encephalasthenia, a reduced ability to work and emotional instability cause disorders in autonomous nervous regulation (Prokhorenko \& Romanenko, 2019). Secondary disorders manifest themselves in insufficient development of mental functions and inmaturity of voluntary forms of behavior. Combination of regulatory and partial disorders causes a lack of wellformed motivational, cognitive and intellectual areas of personality that is insufficient development of voluntary activity, inmaturity of regulation and reflection (Wenger, 1978). The entire system of voluntary regulation of mental activity suffers because of weak control functions of brain-cortex.

Revision of an internal plan of actions and the image of results are elements of reflection allowing an individual to analyze thoroughly, realize and control the activity performed (Popovych et al., 2020b). An individual is aware of their internal regulatory schemes and processes, starts constructing them voluntarily and use a means of management and control over their activity. Reflection ensures reconstruction, transformation of the experience gained and application of it while generating an idea of solving a problem that was confirmed in adaptation processes (Blynova et al., 2020a; 2020e), educational activities (Halian et al., 2020), social work and social support (Blynova et al., 2020b), training and competition activities (Griban et al., 2019; Shkola et al., 2019) and in other types of activities (Nosov et al., 2020a; 2020b).

Hypothesis. We assume that the formation of reflective-evaluative competence will enable pupils with intellectual disabilities to set tasks and solve problems independently that will contribute to improvement of their educational activity and self-development.

The aim. To conduct empirical research on the formation of reflective-evaluative competence in primary pupils with intellectual disabilities; find effective instruments to form it by means of selfcontrol, self-esteem and reflection.

\section{Methodology}

The methodological foundation of the empirical research on reflective-evaluative competence in pupils with intellectual disabilities depends on a number of different tendencies: a) disorders in cortex regulatory systems, lack of purposefulness, programming and control in pupils with intellectual disabilities determine peculiar features in their educational activities; b) special correction-development work aimed at forming reflection, self-control and self-esteem in education will promote the development of reflective-evaluative competence oriented towards independent control over education; c) well-formed reflective-evaluative competence enables a child to make a number of interrelated decisions independently, make a number of coordinated choices as overcoming different aspects of subjective informational uncertainty in planning and managing their own activity, from setting an aim to evaluating and making corrections to the obtained results.

In order to develop the algorithm of empirical research, we used empirical models tested in a number of modern studies on subjective activity (Blynova et al., 2020d; 2021), educational activity (Popovych et al., 2020a; Miyer et al., 2021a; 2021b), psycho-correction work (Drozd \& Bystrova, 2020) and in other studies related to our problem (Blynova et al., 2020c). The analyzed empirical studies are directly related to our empirical research.

Participants. The research involved the participation of primary pupils from the schools of Kyiv (Kyiv, Ukraine), Odesa (Odesa, Ukraine) and Kherson regions (Kherson, Ukraine). The sampled population consisted of: 108 pupils - children with intellectual disabilities and 104 pupils - children with normal-typical development. The total number of the research participants -212 children aged $6-10$ years (SD $=1.71)$. The randomly formed sampled population and the total number of the research participants ensured the parameter of reliability with a low error of the obtained results.

Organization of research. The empirical research was conducted in November 2019 December 2020. The administrations of all the educational institutions gave a permission to carry out the research. The permission of the Research Ethics Committee (REC) to do "The research on reflective-evaluative competence in pupils with intellectual disabilities" was also received. The primary pupils were informed of the research and participated in it voluntarily. All the participants were given information about confidentiality of data collection and conditions for participation. Confidentiality and awareness of the rights and voluntary participation ensured 


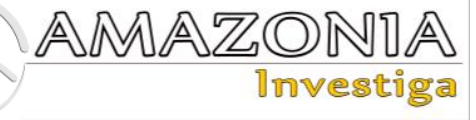

high probability of data reliability. The researchers followed the ethical norms of WMA Declaration of Helsinki (2013).

Procedures and instruments. To examine reflective-evaluative competence in pupils with intellectual disabilities we determined the following criteria:

1) reflection - the depth of forecasting; making a decision, making a choice, generalizing and differentiating one's own opportunities and requirements of activity;

2) self-control - internal-intellectual analysis of operational composition of actions to identify their compliance/non-compliance with the specifics of a problem situation, imaginary and real final results; analysis of the strategy of solving a problem;

3) self-esteem - determining the degree of appropriateness of the adopted general method of solving a problem that allows transition to practical performance of certain actions.

We used the following methods: "Diagnostics of reflection in primary pupils" by L. Prokhorenko (2015) and methodological techniques of the system of developing education V. Davydov (2000). We also applied the methods to check the logic of motivating dialogue, comparative analysis, quantitative and qualitative contentanalysis.

To examine the formation of reflection in primary pupils with intellectual disabilities, we developed the proprietary method "Diagnostics

of reflection in primary pupils" (Prokhorenko, 2015). A pupil was offered a form with wordsanagrams. A child was supposed to make a word using those anagrams by transposing the letters (for example: “д е м" - “мед”). The examples of the words are given in the language of the experiment (in Ukrainian). This method can be adapted to any other language space. We recommend that adaptation should be made by a professional-researcher with work experience of more than two years. After performing the task, the children were offered a key-table to check the anagram solving. The pupils of the first and second years of study were provided with support. The research was carried out in an individual form. After finishing the task, the pupils informed of the way of solving the anagram. The results were processed by three parameters: 1) the coefficient of reflection development; 2) the time spent to perform the task; 3) the ranking index of complexity of the anagrams solved.

The index of reflection development was evaluated in the following way: each anagram solved correctly was rated one point. The coefficient of reflection development was determined as a ratio of a pupil's points to their maximal number. The index of time is an arithmetic mean of the time spent to solve the anagrams. The ranking index corresponds to the number of the most difficult anagram. Qualitative analysis was used to determine the intellectual process: chaotic, formal-algorithmic, informative-adaptive and internal. The level of reflection development $(\mathrm{K})$ is given in Tabl. 1 .

Table 1.

Determination of the coefficient of the level of reflection development $(K)$ of the research participants.

\begin{tabular}{ll}
\hline Level & Value of the coefficient, $\mathbf{K}$ \\
\hline Low & $0.00-0.30$ \\
Medium & $0.31-0.70$ \\
High & $0.71-1.00$ \\
\hline
\end{tabular}

Note: $\mathrm{K}$ - the coefficient of the level of reflection development.

To examine self-control and self-esteem, we used the method by V. Davydov (2000). This method implied performing tasks in three situations: 1) "situation of success" - to perform a task of a familiar structure; 2) "situation of intellectual disruption" - a task with one or two requirements changed; 3) "situation of identifying disruption" - problem tasks of a new type.
To examine the formation of self-control and self-esteem we prepared situations in which the participants stopped performing a reflective task. A pupil was supposed to realize a new problem that arose. A new aim was set to solve it provoking review of the correlation between the components of knowledge and skills acquired. We identified the formation of self-control and self-esteem abilities and determined the necessity of psycho-correction in the "situation of success". In the situation of "intellectual 
disruption" - we registered the children's awareness of the problem that arose and a new aim to solve it, the ability to actualize, generalize and systematize the knowledge and skills acquired. In the situation of "identifying disruption" (performing a problem task) - we registered the children's motifs. The pupils had to test "deficit of their skills".

We evaluated all the tasks. The estimations were transformed into points by the following criteria: the "situation of success" - making a plan to perform the task (1 point), choosing a correct mode of action and applying it (1 point), making a decision on correction (if it is necessary) - (1 point); the situation of "intellectual disruption" awareness of the problem that arose ( 3 points), setting a new aim (3 points), actualizing the knowledge and skills acquired (3 points); the situation of "identifying disruption" - the mode of action is transformed immediately and easily (5 points), the mode of action is transformed slowly, several variants of performing a task are picked, mistakes are made ( 3 points), the mode of action is transformed chaotically, with serious mistakes ( 1 point), there is no transformation of the mode of action ( 0 point $)$.

\section{Statistical analysis}

The obtained results were processed with the software "SPSS" v. 24.0. Arithmetic mean value of parameters $(\mathrm{M})$ and mean-square deviation (SD) were calculated. We used the parameter of reliability Cronbach- $\alpha$, that was recorded at the level $\alpha=.812$ (good) for the first method and at the level $\alpha=.742$ for the second method (satisfactory). The psycho-diagnostic methods and the suggested criteria for examining reflective-evaluative competence allowed obtaining reliable data.

\section{Results and discussion}

Interpretation of the obtained results by the method of diagnosing reflection (Prokhorenko, $2015)$ is given in Fig. 1.

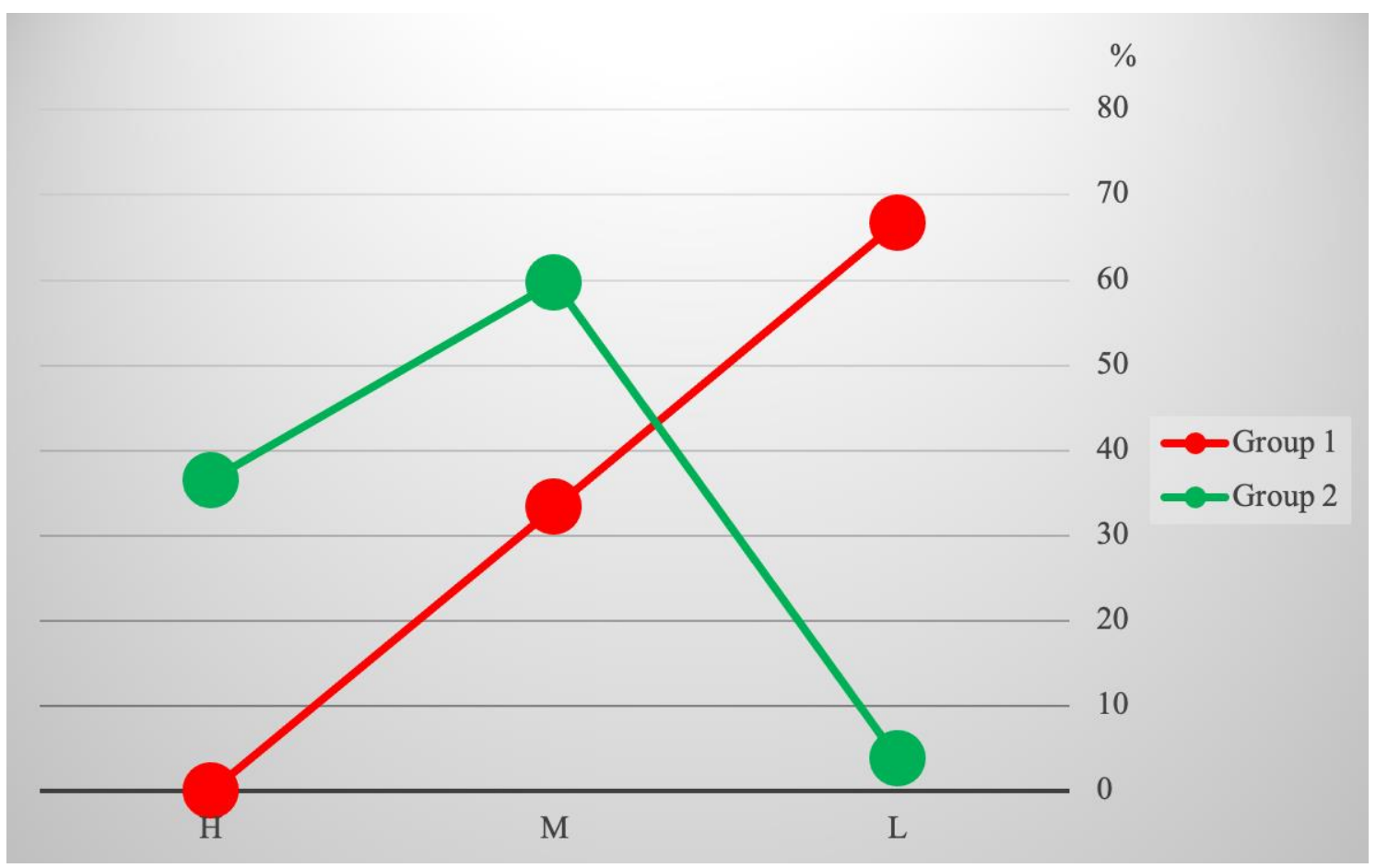

Note: Group 1 - primary pupils with intellectual disabilities; Group 2 - primary pupils with normal-typical development; $\mathrm{H}$ - high level; $\mathrm{M}$ - medium level; L - low level.

Figure 1. The graph of comparison of the primary pupils by the levels of reflection development.

We established that $66.7 \%$ of the primary pupils with intellectual disabilities have a low level of reflection $(\mathrm{K}=0.00-0.01)$ according to the results of the anagrams solved. The children performed chaotic actions, made words by transposing different letters, invented new words using a letter or some analogies, solved correctly not more than three simple anagrams. The algorithm of the succession of spelling letters was not determined when checking the task with a key. For example: Valentyna I., (the $2^{\text {nd }}$ form), wrote the anagram "к і c" as “киця", explaining that "кіс-кіс" is used to call cats. The girl could not explain where the letters " $i$ " and "c" used in 


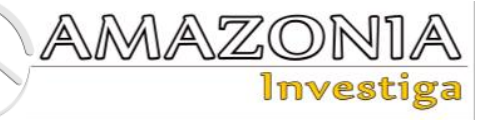

the anagram were in the word “киця", and why her word had more letters ${ }^{50}$. When looking at the key-table, the schoolgirl could not find a relation between the given succession of letter transposition in the anagrams. She received 3 points for performing the tasks, her coefficient of reflection was 0.16 .

$33.3 \%$ of the pupils with intellectual disabilities received 6-9 points, their coefficient of reflection was $K=0.33-0.50$. Among these children there were some pupils who solved correctly 3-5 anagrams and could not explain the interrelation between the given succession of letter transposition in the anagrams without the key-table. The pupils understood the essence of the method of transformation after the adult helped them analyze the key-table.

The way of solving the anagrams shows the pupils' low intellectual activity, inability to explain transformations in the anagrams, find significant correlations between the elements of the task. Their inability to follow the method of performing a task shows that they do not understand the requirements of the tasks. There were no pupils with intellectual disabilities with the coefficient of reflection within $\mathrm{K}=0.55-$ 1.00 .

The primary pupils with normal-typical development also had different results. $3.8 \%$ of the pupils solved correctly only 6-7 anagrams and received the coefficient of reflection within $\mathrm{K}=0.33-0.38$. Thus, reflection in these pupils is formed at a low level. $59.7 \%$ of the pupils were able to draw an analogy in the method of transforming the anagrams in the first and second situations, they had difficulties when solving the third situation, therefore most pupils made words by picking letters. Their coefficients of reflection were within $0.44-0.72$ (8-13 pointss) - a medium level. At the same time, $36.5 \%$ of the pupils had a high level of reflection, they solved the anagrams correctly in all the situations. It is necessary to emphasize that in the third situation there were some difficulties in making words, but the pupils analyzed the method of transforming the previous anagrams that shows the degree of correspondence of each stage of performing the task to its aim. The coefficient of reflection was within $0.77-1.00$ (14-18 points).

The primary pupils with normal-typical development spent much less time to perform the task, from 15 to 30 minutes on the average, the children with a higher coefficient of reflection 10-15 minutes, with a medium level - 20-25 minutes, the children with a low level of reflection solved the anagrams for 30-40 minutes. Unlike these pupils, the schoolchildren with intellectual disabilities with a medium coefficient of reflection performed the task for 40-45 minutes, the children with a low level spent much more time and did not solve complex tasks. The ranking index of complexity was at the level of 8-9. Analysis of the transformation of the third block of anagrams allowed identifying the specifics of the primary pupils' ability to change the strategy of performing the task under difficult conditions.

We determined four levels of reflexivity of the intellectual process on the basis of the obtained data which are given in Tabl. 2.

Table 2.

The levels of reflexivity of the intellectual process.

\begin{tabular}{llll}
\hline Level & $\begin{array}{l}\text { Value of the } \\
\text { coefficient, } \mathbf{K}\end{array}$ & Group 1, \% & Group 2, \% \\
\hline Chaotic & $0.00-0.20$ & 70.0 & 0.0 \\
Formal-algorithmic & $0.21-0.50$ & 30.0 & 3.8 \\
Informative-adaptive & $0.51-0.80$ & 0.0 & 79.8 \\
Internal & $0.81-1.00$ & 0.0 & 16.4 \\
\hline
\end{tabular}

Note: $\mathrm{K}$ - the coefficient of the level of reflection development.

The main characteristics of the chaotic level are disorganized search of solving, using methods which are not related to each other logically, inability to check the obtained result. This level is characteristic of the primary pupils with the coefficient of reflection $K=0.00-0.20$. This level is inherent in most pupils with intellectual disabilities (more than 70.0\%). The formalalgorithmic level differs from the chaotic level by consistent selection of possible methods for

${ }^{50}$ Ukrainian language: the anagrama "к і c" as "киця" (engl. "cat"). 
solving the problems correlating to the previous one, reproductive activity dominates in an informative aspect, however, insufficiently developed regulation - in a logical aspect. This level is inherent of the children with the coefficient of reflection $\mathrm{K}=0.21-0.50$. This level is observed in $30.0 \%$ of the pupils with intellectual disabilities. The informativeadaptive level is characterized by the ability to analyze significant features, transform the method of performing the task according to complex conditions, determine correctness and completeness of the operations constituting the area of reflection. This level is inherent in the children with the coefficient of reflection $\mathrm{K}=$ $0.51-0.80$. The intellectual activity of the pupils with the internal level of reflection development is characterized by brief search of actions and its combination with evaluative search, that allows a pupil to find a correct solution quite quickly. The coefficient of reflection at this level is $\mathrm{K}=$ $0.81-1.00$. There were no children with intellectual disabilities who had informativeadaptive and internal levels of reflection development, those with with normal-typical development -16.4 .

One of the important components of reflectiveevaluative competence is self-control and selfesteem ensuring arbitrariness and regulated character of educational actions examined with the method by V. Davydov (2000). In the first situation the children had to perform simple tasks using familiar methods. Performing tasks in familiar situations did not entail difficulties in the primary pupils with normative-typical development. At the same time the children with intellectual disabilities had some difficulties while choosing the method to perform the task: the mode of action was determined by the method of picking familiar modes, the children reviewed the previous tasks, applied the mode of performing them to the suggested task, asked the teacher about correctness of their choice etc. After guiding questions concerning the method of performing the task and some assistance, the children coped with the task.
The tasks of the second situation entailed more difficulties in the children with intellectual disabilities. We give an example of performing the task by Iryna B, the $3^{\text {rd }}$ form. Having read the problem situation "On the first day the children gathered $4 \mathrm{~kg}$ of vegetables from the plot, on the second day $-2 \mathrm{~kg}$ of vegetables. How many more kilograms did the children gather on the first day?", the girl copied the mode of performing the previous task. When the experimentalist asked her to explain how the mode of performing the task was found, the girl answered that "the task is the same, therefore the actions are also the same". After analyzing the question in the task, the pupil identified the correct way to solve the problem with the assistance of the experimentalist. This mode of performing the task was characteristic of $63.8 \%$ of the primary pupils with intellectual disabilities. It indicates to the inability to correlate a problem situation with the experience gained, to build an algorithm of solving a problem, transform a familiar mode and apply it in changeable conditions. Arbitrariness of educational activity of these pupils depends on complexity of a task, especially on complexity of a programming component and existence of a conflict situation. The necessity to act according to changed conditions, make an imaginary plan in spite of familiar conditions of activity entail considerable difficulties in the course of selfcontrol over one's own performance. On the contrary, all the primary pupils with normaltypical development performed the task successfully. Only $10.5 \%$ of the pupils made mistakes in the plans and modes of actions, but after some guiding questions they reviewed the problem situation, analyzed the question and corrected the solution. The problem tasks in the third situation proved to be difficult for all the pupils with intellectual disabilities. $25.9 \%$ of the children with intellectual disabilities refused to perform the task, $74.1 \%$ of the pupils did not understand the instruction of the task and, as a result, performed it incorrectly.

Interpretation of the obtained results with the method by V. Davydov (2000) is given in Fig. 2. 


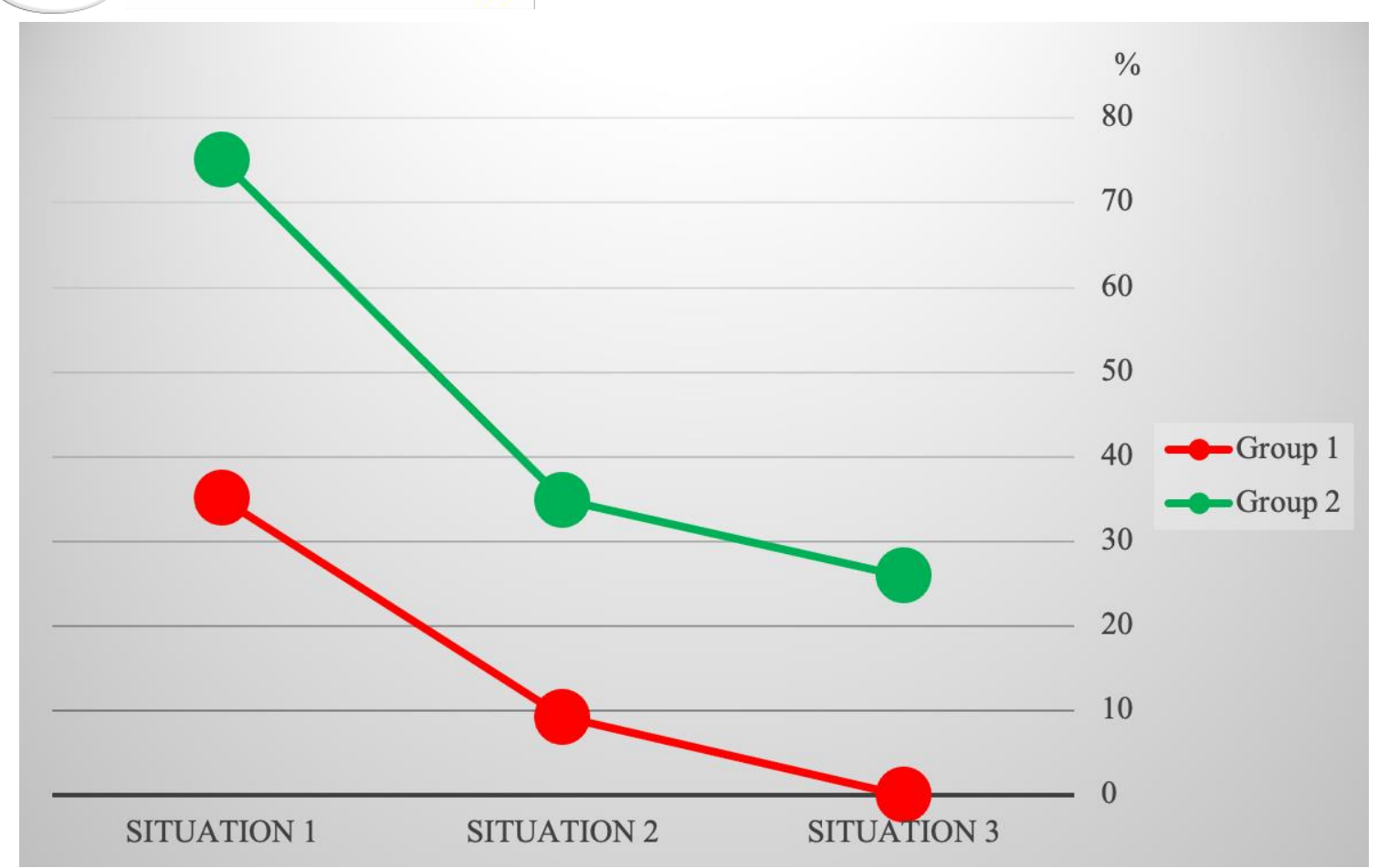

Note: Group 1 - primary pupils with intellectual disabilities; Group 2 - primary pupils with normal-typical development; Situation 1 - "situation of success"; Situation 2 - "situation of intellectual disruption"; Situation 3 - "situation of identifying disruption".

Figure 2. The graph of comparison of the primary pupils in Group 1 and Group 2 who performed the task successfully in three situations.

In total, the obtained results were the following in the three situations. In the "situation of success" $35.1 \%$ of the pupils with intellectual disabilities and $75.0 \%$ of the pupils with normaltypical development performed the task successfully. $60.2 \%$ of the children with intellectual disabilities and $25.0 \%$ of the pupils with normal-typical development made mistakes, but they identified and corrected them with the teacher's assistance. The performance in the children with normal-typical development was higher, they asked the teacher to help them more seldom. When checking the results these children compared the obtained result with the problem situation, however, some children checked the results in another way. The children with intellectual disabilities hardly noticed mistakes, they had considerable difficulties in picking the mode of solving the problem. Most children expected the teacher to help them, they did not compare the final result with the problem situation. However, among the children with intellectual disabilities there were $4.7 \%$ of the children who were not able to plan how to solve the problem without the teacher's help, to determine the mode of actions, check the course of actions and the final result independently. There were no pupils with normal-typical development who did not cope with the task.
The following results were obtained in the "situation of intellectual disruption": $9.2 \%$ of the pupils with intellectual disabilities understood the problem situation properly, analyzed the question, found discrepancy with the previous task, but they had difficulties when transforming the general mode of performing the task in changed conditions. However, with the teacher's assistance, the children performed the task successfully and checked it. While evaluating the course of actions, the children explained the reason of difficulties and evaluated the performance properly, e.g: "performed the task successfully, but made a mistake", "it might be better" etc. Among the primary pupils with normal-typical development, there were $39.4 \%$ of the children who analyzed the problem situation correctly, picked an appropriate mode of action, checked and evaluated the work properly. Most children with intellectual disabilities (59.2\%) had considerable difficulties when performing the task. The children associated the problem situation with the previous one, therefore they chose the mode of action incorrectly without transforming it according to the changed conditions. After analyzing the question in the task with the teacher's assistance, the pupils were able to determine the mode of action correctly. They checked the task superficially. Evaluating their 
performance, the children focused on external factors ("performed the task badly, because a bee had flown into the class-room", "the teacher said, so it must be correct", "performed successfully, but made a mistake because of a friend"). Explaining the changes in the problem situation, when comparing it to the previous one, they focused on superficial characteristics without considering the main ones ("in the first task there were more kilograms of vegetables, and there were less kilograms in the second one", "the questions are similar, they may differ, but I cannot understand the difference", "the first task is shorter" etc). There were $49.1 \%$ of the primary pupils with normal-typical development who performed the task with mistakes, they did not pay attention to the question and mixed up the mode of action, however, when analyzing the problem situation for the second time, the children identified their mistakes, explained them and corrected. Unlike their peers with intellectual disabilities, these children can use the acquired modes of self-control and substantiate the evaluation when the teacher asks them about it.

There were $9.6 \%$ of the primary pupils with intellectual disabilities and $11.5 \%$ of the children with normal-typical development who did not perform the task in this situation, that shows insufficient development of self-control and selfesteem in these children.

In the "situation of identifying disruption", the research results were worse in the children of both groups. All the primary pupils with intellectual disabilities had difficulties when analyzing the problem situation, they could not realize the necessary actions and determine their succession. There were no schoolchildren who understood the problem situation and performed the task independently. $73.2 \%$ of the pupils did not follow the succession and performed chaotic actions not related to the task. $26.8 \%$ of the pupils made mistakes choosing the signs, without analyzing the question, they did not identify the prompt to explain the action and did not complete the task facing difficulties.

Among the pupils with normal-typical development, $25.9 \%$ of the children understood the problem situation correctly, made mistakes when following the stages of solving the problem, however, the children coped with the task with the adult's assistance. $61.6 \%$ of the pupils made mistakes when analyzing the questions, some children filled squares with the words that were not solutions, identified the action by picking, explaining it in the following way, "the sign "-", " +" or " $x$ " could be there, because 7 is not divided by 3 ", these children coped with the task after the repeated explanation. However, $12.5 \%$ of the children made mistakes, some of them did not analyze the problem situation and refused to solve it because of the difficulties.

The obtained data show that the primary pupils with intellectual disabilities start acting by trial and error, they do not associate the problem situation with the aim and the method of solving it. The practical operations performed by the pupils do not "diverge" from the externally oriented model that does not allow them to perform these operations in the internalintellectual dimension.

\section{Discussions}

In scientific literature there is a number of studies about intellectual disabilities in schoolchildren of different age (Drozd \& Bystrova, 2020; Prokhorenko \& Kostenko, 2020; Yakovleva, 2019). However, we found no research on reflective-evaluative competence of primary pupils. But there are studies related to the subject of our scientific search. It is obvious that functional mechanisms of reflective-evaluative competence - self-control, self-esteem and reflection - have special regulatory significance in educational activity because they ensure control over putting a plan into action, evaluating the obtained result, associating it with the aim, correcting those changes that occur in both the subject of activity and the mechanism of its regulation. The psychological mechanism of reflection plays a key role in the context of the above mentioned information. Empirical studies on reflection as evaluative process correspond to the results of our research (Zaporozhets, 1986). Other studies show that reflection is determined by the processes of processing information corresponding to the regulatory functions of planning, modelling, programming, evaluating and correcting different forms of mental activity (Mislavsky, 1988). The scientific facts we established are proved by the view of the scientists who consider evaluative competence as systemic-organized process of internal mental activity of an individual directing voluntary activity and ensuring achievement of the outlined aim of activity immediately. General regularities of the formation of an estimation are based on regulatory informational processes. Evaluative competence includes informational processes, actions and their performance. It confirms the obtained empirical data about reflectiveevaluative competence of primary pupils. 
The opinion that reflection implies selfobservation and self-analysis is convincing. It means that an individual can realize and control their activity (behavior), regulate their actions and self-development if they have well-formed reflection (Piaget, 1977; Bandura, 1994). In particular, some studies (Bandura, 1994; Baumeister, 2014) consider self-control and selfesteem to be highly important for organizing regulatory processes. The researchers emphasize internal and external regulation of an individual's activity. Internal regulation implies the development of volitional qualities, the ability to organize activity and perform it purposefully. External regulation implies the availability of external control in organizing, making a plan, succession and control over the results of activity.

The researchers T. Sak (2014) and V. Sinov (2007) paid their attention to a regulatory component of a general ability to learn of individuals with normal-typical development and children with special needs (with disorders in cognitive development, pupils with intellectual disabilities, with general difficulties in education, caused by different mental disorders). The authors confirm that differences in the development of self-control and reflection in education are considered to be an essential difference between educational-cognitive activity of children with normal-typical development and children with intellectual disorders. The obtained data of our research and the study of T. Sak (2014) and V. Sinov (2007) confirm that these children have underdeveloped motivational, orientation, operational and reflective components of activity, namely: a lack of understanding of the requirements to activity, difficulties in the process of performing it, inability to perform a number of intellectual actions step by step, compare the performance with the example, make conclusions, a constant need of an adult's assistance.

Some psychological studies focus on specific manifestations of reflection in different activities of children with intellectual disabilities including: deviations in manifestations of volitional regulation reflected in permanent inadequate behavior; inability to evaluate a situation critically; inability to plan how to perform activity, correct their mistakes; manifestations of inadequate self-esteem (Prokhorenko, 2015; Prokhorenko \& Kostenko, 2020).
We should emphasize that the result of activity depends on reflective actions, in particular, on arbitrary construction of rules, assumptions, situations. Thus, reflection allows predicting different variants and conditions when making a plan of activity, determining those criteria that will contribute to effective implementation of a plan. At the same time, self-reflection unites functions of intellectual operation and management of one's own activity resulting in changes of this activity: a planned or realized algorithm is re-evaluated, a new model of solving the problem is created. It means that reflectiveevaluative competence is one of the main conditions for the formation of cognitive activity. The result of reflective-evaluative competence is changes in activity: re-evaluation of the existing plan to achieve an imaginary result, intellectual correction of the activity in terms of its compliance with the suggested criteria, creation of a new program of actions according to the improved criteria. Reflective-evaluative competence involves the following components: struggle of motifs, intellectual self-control, review and evaluation of one's own activity, reconstruction and correction of the available idea.

The research on reflective-evaluative competence of pupils with intellectual disabilities establishes that underdeveloped process of reflection is in disruption of a forecasting function of thinking. Children are able to control their own actions if there is a sample. In the situations, in which it is necessary to perform intellectual analysis of the mode of action, change or reconstruct the idea, there is a reduction in intellectual activity, refusal to carry on implementing the plan, a lack of inclination to cope with the problems arising in the process of implementation, that has a negative impact on self-correction of the activity. Insufficient selfcontrol and low self-esteem manifest themselves in the specifics of programming activity and performing it by pupils with intellectual disabilities. The ability of a child with intellectual disabilities to understand simple instructions, to plan and determine familiar modes of action makes it possible to draw a conclusion with regard to the formation of their ability to perform a task in familiar situation, however, if the conditions are changed, children find it difficult to determine the succession of performing the task, to evaluate its compliance with the aim and assess the strategy and possibilities of variability under changeable conditions of activity. It has a negative impact on their ability to control, regulate and correct the task performance independently. 
Taking into consideration the fact that firstly a child realizes external and then internal structures of the individual experience, we think that the formation of reflective-evaluative competence should occur in the following way: reproduction of familiar schemes, modes and patterns of actual activity; intellectual review and correction of the scheme and means of the activity performed; intellectual analysis, selfcontrol and self-correction of future activity.

The obtained quantitative indexes and qualitative characteristics enable us to generalize that insufficient development of regulation mechanisms, namely, inability to analyze essential situations from the point of view of solving this or that problem, inability to figure out aims and future results and act in the internalintellectual dimension - have a negative impact on educational activity of primary pupils with intellectual disabilities.

In future, a step-by-step correction-development program of forming reflective-evaluative competence will be developed, in particular: the first stage - intellectual review of one's own actions occurring in the course of performing activity; the second stage - reproduction and analysis of actions after performing activity; the third stage - reflective analysis of the planned actions on the basis of the obtained generalized experience in the current and retrospective reflection and the fourth stage - on the basis of reflection development - mastering the modes of correcting activity. In addition, we formulated the assumption that purposeful formation of reflective-evaluative competence facilitates the mobility of a child with intellectual disabilities in education, the ability to perceive the content and conditions of educational tasks properly, the formation of abilities to find an appropriate strategy to perform and implement activity, manage and improve the course of one's own activity under different conditions of its realization. This assumption requires further theoretical and empirical research.

\section{Conclusions}

1) We established that insufficient development of reflective-evaluative competence in children with intellectual disabilities is largely observed in their performing complex tasks, existence of a conflict situation that has a negative impact on self-control of their work.

2) We maintain that insufficient development of self-control and self-esteem are interrelated with insufficient development of reflection: inability to associate a problem situation with the experience gained, construct an algorithm of performing a task, transform a familiar mode and apply it under changeable conditions.

3) We determined that under complicated conditions, when performing a task of a new type where the result of action does not correspond to a familiar mode and it is necessary to find a right solution, primary pupils with intellectual disabilities start acting by trial and error, without considering a problem situation and the mode of performing the task. Operations performed by them do not "diverge" from an externally oriented model.

4) We emphasize that characteristic features of reflective-evaluative competence of primary pupils with intellectual disabilities include: inability to analyze essentials situations for solving this or that problem; inability to compare and analyze the correlation between aims and future results; faults in internal-intellectual planning; inability to control and correct the performance of actions.

5) We identified defects of self-esteem and self-correction existing in the functional insufficiency of the processes of modelling and evaluating results that has a negative impact on planning a task, in particular: an algorithm for solving a problem is not constructed, the plan of actions is not associated with the aim, the mode of performing a task is not analyzed and outlined distinctly. Pupils with intellectual disabilities can exercise self-control when comparing their results with the answers. They do not control the course of activity and the result obtained in unfamiliar situations, that causes numerous mistakes.

6) We established that primary pupils with intellectual disabilities realize the importance of checking their work and try to act according to the rules (requirements), following them in their activity during a particular period of time. It indicates to possibility of self-control development in these children under conditions of correction-development work.

7) $\mathrm{We}$ generalize that reflective-evaluative competence will be formed most effectively on the basis of transition from inter-mental to intra-mental form where the agent of reflection is a class, then - a group of pupils, and later, a pupil.

8) We make a conclusion that the hypothesis is confirmed, and the obtained empirical 


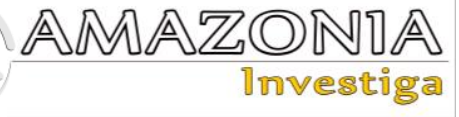

results and theoretical substantiation of the formation of reflective-evaluative competence in pupils with intellectual disabilities are valuable from a scientific point of view. Operationalization of the research results in educational process will contribute to creating inclusive educational space and solving didactical problems.

\section{Bibliographic References}

Bandura, A. (1994). Social cognitive theory and mass communication. Hillsdale, NJ: Erlbaum.

Baumeister, R. F. (2014). Self-regulation, ego depletion, and inhibition. Neuropsychologia, 65, 313-319.

Blynova, O., Chervinska, I., Kazibekova, V., Bokshan, H., Yakovleva, S., Zaverukha, O., \& Popovych, I. (2020a). Social and Psychological Manifestations of Professional Identity Crisis of Labor Migrants. Revista Inclusiones, 7(3), 93-105. http://www.revistainclusiones.org/index.php /inclu/article/view/1318

Blynova, O., Kisil, Z., Tkach, T., Semenova, N., Semenov, O., Kamisnka, S., \& Popovych, I. (2020b). Psychological manifestations of professional marginality of future social welfare professionals. Revista Inclusiones, $7(\mathrm{SI})$, 218-233. http://www.revistainclusiones.org/index.php /inclu/article/view/1229

Blynova, O., Kostenko, T., Nesin, Y., Fedorova, O., Chaban, O., Pyslar, A., \& Popovych, I. (2021). Research of the Relationship between Perfectionism and Feelings of Loneliness of Youths. Postmodern Openings, 12(2), 01-17. https://doi.org/10.18662/po/12.2/294

Blynova, O., Lappo, V., Kalenchuk, V., Agarkov, O., Shramko, I., Lymarenko, L., \& Popovych, I. (2020c). Corporate Culture of a Higher Education Institution as a Factor in Forming Students' Professional Identity. Revista Inclusiones, 7(SI), 481-496. http://www.revistainclusiones.org/index.php /inclu/article/view/1305

Blynova, O., $\quad$ Moiseienko, V., Los, O., Burlakova, I., Yevdokimova, O., Toba, M., \& Popovych, I. (2020d). Assertiveness as a Factor of Students' Choice of Behavior Strategies in Social Interaction. Revista Inclusiones, 7(4), 259-272. http://www.revistainclusiones.org/index.php /inclu/article/view/1551

Blynova, O., Popovych, I., Semenova, N., Kashyrina, Ye., Ursulenko, O., \& Kononenko, O. (2020e). Personality Factors of Choosing Adaptation Strategies in a
Different Cultural Environment by Labor Migrants from Ukraine. Revista Amazonia Investiga, 9(32), 45-54. Retrieved from http://dx.doi.org/10.34069/AI/2020.32.08.5

Davydov, V. V. (2000). Types of generalization in teaching: Logical and psychological problems of constructing educational subjects. Moscow: Pedagogical Society of Russia. http://childpsy.ru/lib/books/id/8313.php

Drozd, L.V., \& Bystrova, Yu. O. (2020). Features of communication of adolescents with intellectual disabilities in the interpersonal relations. Insight: the psychological dimensions of society, 3, 123-133. https://doi.org/10.32999/2663970X/2020-3-9

Griban, G., Prontenko, K., Yavorska, T., Bezpaliy, S., Bublei, T., Marushchak, M., Pustoliakova, L., Andreychuk, V., Tkachenko, P., Zhukovskyi, Ye., Baldetskiy, A., \& Bloshchynskyi, I. (2019). Non-traditional means of physical training in middle school physical education classes. International Journal of Applied Exercise Physiology, $8(3.1), \quad 224-32$. DOI: $10.26655 /$ IJAEP.2019.10.1

Halian, I.,

Machynska, N., Lozynska, S., Nos, L., Derkach, Yu., Prots, M., \& Popovych, I. (2020). Tolerance of uncertainty as a component of the process of life-creation of future educators. Revista Inclusiones, $\quad 7$ (SI), 512-528. http://www.revistainclusiones.org/index.php /inclu/article/view/1307

Khmiliar, O., Popovych, I., Hrys, A., Pavliuk, M., Zavatska, N., Lytvynenko, O., \& Blynova, O. (2020). Spatial Regulation of Personality Behavior in the Conditions of Progression of the COVID-19 Pandemic. Revista Inclusiones, 7(Especial), 289-306. http://www.revistainclusiones.org/index.php /inclu/article/view/1760

Konopkin, O. A. (2012). Conscious selfregulation as a criterion of subjectivity. Bulletin of the practical psychology of education, 4 , 97-101. https://elibrary.ru/item.asp?id=37401776

Kopp, C. B. (1982). Antecedents of selfRegulation a developmental perspective. Developmental Psychology, 18(2), 199-214.

Lubovsky, V. I. (1989). Psychological problems of diagnosing anomalous development of children. Moscow: Pedagogy.

Luria, A. R. (1996). Neuropsychology and problems of education in secondary schools. Moscow:

IPP. http://childpsy.ru/lib/books/id/8250.php

Martel, M. M. (2007). Childhood and adolescent 
resiliency, regulation, and executive functioning in relation to adolescent problems and competence in a high-risk sample. Development and Psychopathology, 19, 541-563.

Mislavsky, Yu. A. (1988). Self-regulation and creative activity of the personality. Questions of psychology, 3, 71-78.

Miyer, T., Holodiuk, L., Omelchuk, S., Savosh, V., Bondarenko, H., Romanenko, L., \& Romanenko, K. (2021a). An Overview of the Continuous Education System Components in Dimensions "Umwelt", "Mitwelt" and "Eigenwelt". AD ALTA: Journal of Interdisciplinary Research, 11(1), 52-56.

http://www.magnanimitas.cz/ADALTA/110 117/papers/A_10.pdf

Miyer, T., Holodiuk, L., Omelchuk, S., Savosh, V., Bondarenko, H., Rudenko, N., \& Shpitsa, R. (2021b). ICT as a Means of Implementing thematic FIN-modeling in the organization of training in institutions of higher pedagogical and adult education. AD ALTA: Journal of Interdisciplinary Research, 11(1), 26-32. http://www.magnanimitas.cz/ADALTA/110 118/papers/A_05.pdf

Nosov, P., Palamarchuk, I., Zinchenko, S., Popovych, I., Nahrybelnyi, Y., \& Nosova, H. (2020a). Development of means for experimental identification of navigator attention in ergatic systems of maritime transport. Bulletin of the University of Karaganda - Physics, 1(97), 58-69, 0.31489/2019Ph1/58-69

Nosov, P. S., Zinchenko, S. M., Popovych, I. S., Ben, A. P., Nahrybelnyi Y. A., \& Mateichuk, V. M. (2020b). Diagnostic system of perception of navigation danger when implementation complicated maneuvers. Radio Electronics, Computer Science, Control, 1, 146-161. https://doi.org/10.15588/1607-3274-2020-115

Osnitskii, A. (2001). The structure, content and functions of person's regulatory experience. (Extended abstract of Doctor's thesis). RAS Psychological Institute. Moscow. http://www.dslib.net/obwajapsixologia/struktura-soderzhanie-i-funkciireguljatornogo-opyta-cheloveka.html

Piaget, J. (1977). Recherches sur l'abstraction reflechissantes. Paris: PUF.

Popovych, I., Laliuk, G., Aleksieieva, M., Popovych, A., Bondarenko, V., Kovtun, O. \& Tsiuniak, O. (2020a). Sociocultural metrics of the personal paradigm of orphans' upbringing in pedagogical theory and practice of Ukraine. Revista Inclusiones, 7(3), 343-356. http://www.revistainclusiones.org/index.php /inclu/article/view/1638

Popovych, I., Zhigarenko, I., Losiyevska, O., Dovbenko, S., Kashyrina, Ye., Shevchenko, R., \& Piletska, L. (2020b). Research of Achievement Motivation's Impaction the Career Orientations of Future Managers of Organization. Revista Inclusiones, 7(SI), 247-263. http://www.revistainclusiones.org/index.php /inclu/article/view/1231

Prokhorenko, L. I., \& Kostenko, T. M. (2020). Research of psychological and pedagogical typologization of mental developmental delay of schoolchildren. Insight: the psychological dimensions of society, 4, 111-131. https://doi.org/10.32999/2663970X/2020-4-7

Prokhorenko, L. I. (2015). Formation of selfregulation in mathematics lessons in primary school children with mental retardation. Chernivtsi,

Bukrek. http://catalog.odnb.odessa.ua/opac/index.php ?url=/notices/index/IdNotice:324222/Source :default

Prokhorenko, L. I., \& Romanenko, O. V. (2019). Specificity of classifying objects of informational area by children with mental retardation. Information Technologies and Learning Tools, 74(6), 266-277. http://nbuv.gov.ua/UJRN/ITZN_2019_74_6 -22

Prokhorov, A. O. (2005). Self-regulation of mental states: phenomenology, mechanisms, patterns. Moscow: Nauka. https://biblioclub.ru/index.php?page=book \& $\mathrm{id}=86332$

Romanenko, O. V. (2020). The development of sensory-perceptual processes of the psyche in conditions of norm and organic pathology (CP). Insight: the psychological dimensions of society, 4, 132-144. https://doi.org/10.32999/2663-970X/2020-48

Sak, T.W. (2014). A differentiating approach to teaching pupils with special educational needs. Scientific Bulletin of the NPU named after M. P. Drahomanov. Series 19: Correction pedagogy and special psychology, 26, 215-219. http://enpuir.npu.edu.ua/handle/123456789/ 7718

Shatskaya, I. (2021). Assessment of the quality of the educational process for students with disabilities. Apuntes Universitarios, 11(4), 548-559. 


\section{AMAZONDA \\ 1nvestig.}

https://apuntesuniversitarios.upeu.edu.pe/ind ex.php/revapuntes/article/view/856

Shevchenko, R., Cherniavskyi, V., Zinchenko, S., Palchynska, M., Bondarevich, S., Nosov, P., \& Popovych, I. (2020). Research of psychophysiological features of response to stress situations by future sailors. Revista Inclusiones, 7(SI), 566-579.

http://www.revistainclusiones.org/index.php /inclu/article/view/1780

Shkola, O., Griban, G., Prontenko, K., Fomenko, O., Zhamardiy, V., Bondarenko, V., Bezpaliy, S., Andreychuk, V., Tkachenko, P., Zhukovskyi, Ye., Novitska, I., \& Bloshchynskyi, I. (2019). Formation of valuable orientations in youth during physical training. International Journal of Applied Exercise Physiology, 8(3.1), 264-272. DOI: 10.26655/IJAEP.2019.10.1

Sinov, V. M. (2007). Correction psychopedagogy. Oligophrenopedagogy. Kyiv: The Publishing House of the NPU named after M. P. Drahomanov.

https://ua1lib.org/book/3265418/5d4d81 ?id= 3265418 \&secret $=5 \mathrm{~d} 4 \mathrm{~d} 81$
Torrance, E. P. (1974). Torrance tests of creative thinking. Bensenville, IL: Scholastic Testing Service.

https://www.scirp.org/(S(351jmbntvnsjt1aad kposzje))/reference/referencespapers.aspx?re ferenceid $=876051$

Wenger, L. A. (1978). Diagnostics of intellectual development in preschoolers. Moscow: Pedagogy. http://childpsy.ru/lib/books/id/8235.php

World Medical Association Declaration of Helsinki. (2013). Ethical principles for medical research involving human subjects. JAMA， 310(20), 2191-4. https://doi.org/10.1001/jama.2013.281053

Yakovleva, S. D. (2019). Individualization and differentiation at teaching of pupils with cognitive development disorders. Insight: the psychological dimensions of society, 1, 110-116. https://doi.org/10.32999/2663970X/2019-1-17

Zaporozhets, A. V. (1986). Mental development of a child. Moscow: Pedagogy. http://театршкола.екатеринбург.pф/file/16 6a54bf1eb95fceada11e498e4bab86 